\title{
Exploring Knowledge Sharing Practices among Paddy Farmers towards Building a Foundation for Knowledge Creation
}

\author{
Hanis Diyana Kamarudin, Nor Erlissa Abd Aziz, Muhammad Khairulnizam Zaini, and Nor Zaina \\ Zaharah Mohd Ariff
}

\begin{abstract}
The importance of knowledge sharing within a country whether at central, regional nor local governments has been largely overlooked. In a knowledge based economy, performance and productivity are the factors that crucial in determining success factors. This is an indicator of the sustainability of economic development. Competencies, skills and knowledge are the imperative components to achieve the competitive advantage for individual and organization. Learning becomes as an important activity to improve the skills, competencies and knowledge. The learning process is an important element to facilitate decision making at personal, organizational and societal levels. Similarly, in the agricultural sector where important decision is made in planning, marketing, research and development, production, etc., undoubtedly knowledge sharing is an important practice to help farmers and other stakeholders in gaining better productivity. This paper presents findings of a recent study on knowledge sharing practices among paddy farmers in Selangor granary areas. Eight paddy farmers' representatives were questioned on their experience and livelihood, individually and as members of a larger community of practitioners. Through this case study, the reports enable readers to understand the pattern of knowledge sharing among farmers and good practices at the community level being put to good use. The findings of the study can be reused, hence making learning and education among farmers become more efficient.
\end{abstract}

Index Terms - Generation and dissemination of information, knowledge management, learning, paddy farmer.

\section{INTRODUCTION}

A food crisis issue which hit the world recently affects many countries. Demand increases dramatically to world main cereal such as wheat, rice and corn. Global concern sparked this crisis result in foodstuff prices and shortage of rice supply. Most major food crisis in the world population caused by high demand whereas the supply to world population unable to fulfill the requirements. A supply crisis brought adverse impact which encountered by most of the countries that import rice to occupy their population including our country. According to data provided by [1], rice productions in our countries accommodate about 70 percent of people demand and the remainder need to be imported. In a crisis situation like today, Thailand and Vietnam which known as largest rice world exporter already strive to increase the productivity because they know world

Manuscript received October 1, 2013; revised December 2, 2013.

Hanis Diyana Kamarudin is with the Universiti Teknologi MARA, Malaysia (e-mail: hanisdiyana@salam.uitm.edu.my). rice supply will not enough. The country imports 30 percent of rice which cost an exorbitant amount (RM725 million in 2008) to the overall expenditure and the productivity level has been the same for a few years.

On the local scene, agriculture is a major contributor to the national economy, hence it is imperative that the agricultural sector be given full attention especially in the education and training of farmers. Special attention needs to be given to technical matters, R\&D and entrepreneurship in order to turn the farmers into knowledge workers who could share, utilize and generate good practices for the benefit of their fraternity.

\section{LITERATURE REVIEW}

Knowledge management involves capturing, organizing, distributing, sharing, and use of the intellectual assets of an organization, a community or a nation for the benefit of its stakeholders, members and citizen. It is believed that the knowledge sharing is crucial in the agricultural industry where people need to exchange and share their data and knowledge in order to increase the yield productivity level.

According to [2], there is a fear of a lot of traditional knowledge becoming obsolete because of lack of communication. For example in medieval India the art of fine, thin muslin was well known. The art died because the weavers were reluctant to share this art with others. This happened because transfer of work skills and traditional knowledge remained the individual privilege and was guarded by communities for centuries.

Knowledge sharing is the process where individuals mutually exchange their knowledge with two occurring activities; bringing (donating) knowledge and getting (collecting) knowledge [3]. Knowledge sharing promotes trust and mutual respect as well as facilitating the flow of one's knowledge assets to be capitalized for performance improvements.

A study conducted by [4] in 2006 indicate that sources in diffusion of innovations among farmers are from their peers, extension agents, sales person and others such as rice millers. Nonetheless, the peers play the most significant role in spreading the innovations. The respondents explained that they faced a communication problem with the extension agents. Based on study conducted, the respondents also felt that the role of extension agents is less important and they prefer to depend upon their farming experiences.

A survey led by [5] in (2010) indicated that the Japanese agricultural agencies are actively involved in facilitating an 
integrated knowledge creation and sharing initiatives within their organizations. On the other hand, the extension advisors, who act as intermediaries and catalysts, are the key links between farmers and the relevant authorities in terms of personalized and need-based information for decision making by all parties concerned. If data is not available to farmers who are attempting to adopt sustainable practices, they may need to bring forth such data on their own. However the cost of information generation may be too high for an individual farmer.

[6] stated that low levels of education and knowledge among the farmers become one of the challenges in agriculture field. They face difficulties understanding the intricacies of running warehouse receipting schemes, contract farming arrangements and general interaction with the business community on their own. This is where knowledge plays important roles to supervising farmers in the decision making process.

\section{MEthodOlOGY}

A study was carried out in a major rice-producing area, central region of the Peninsula with the aim of identifying factors that contribute to their ability to produce rice at a rate that is above the national production average. Eight paddy farmers' representatives were questioned on their experience and livelihood, individually and as members of a larger community of practitioners.

\section{RESULTS AND DISCUSSION}

IADA Barat Laut Selangor is one of the rice producing regions under Ministry of Agriculture and Agro-Based Industry Malaysia. Agriculture remains an important sector of Malaysia's economy, contributing 12 per cent to the national GDP and providing employment for 16 per cent of the population. In the year 2010, over 9,200 paddy farmers of Selangor have produced 5.61 tonnes per hectare (tph), which is more than the national average of $4.1 \mathrm{tph}$.

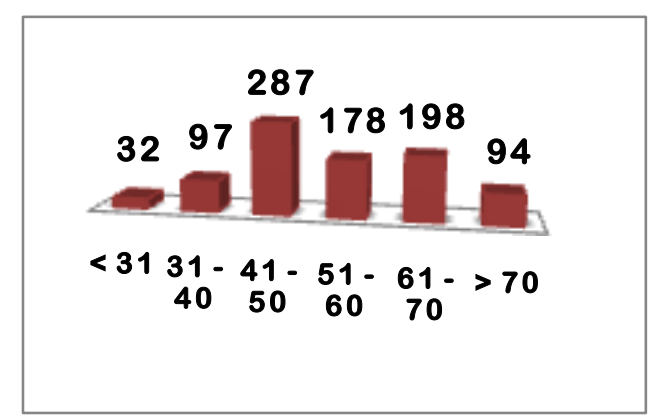

Fig. 1. Paddy farmers' average age is 53 years, minimum 18 years, maximum 92 years old.

\section{A. Formal and Informal Learning, Visits and Training}

Education and training enrich farmers' ability and willingness to make efficacious changes in their management practice. The training program is generally considered as one of several factors which influence participants to make changes in their practice.

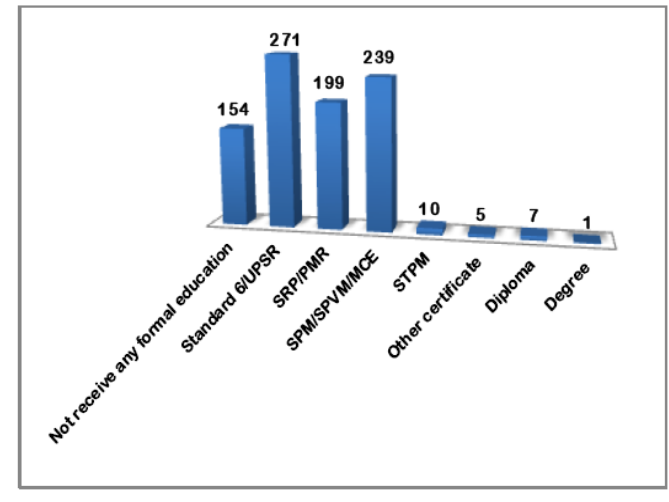

Fig. 2. Paddy farmers' education level.

Based on Fig. 2, the majority (271 respondents) received formal education from school until standard 6/UPSR, followed by SPM/SPMV/MCE (239 respondents). Out of 886 farmers, only one respondent received formal education until degree level.

Farmers, those working in the field also require both formal and informal learning to discover and practice new skills. Farmers aware that agriculture is a risky business, hence every decision made should be accurate and timely to facilitate decision making [5]. The learning process is not just only limited to the classroom, seminar or workshop. Based on the case study conducted, it was found that informal learning and training happen every day.

Development activities have been conducted in both rice producing areas. There are extension officers on duty in each area to be on the field. Their responsibility is to facilitate and communicate with farmers on various issues related to paddy farming activities. Normally farmers will gain advice from extension officers. From the interview it was reported that active learning happened between farmers and extension officers.

In IADA Barat Laut Selangor, the extension officers are more approachable. Farmers do not have to pay their visit to the agriculture offices. Regular visits and training will be conducted by the extension officers to a farmer's residence as new agricultural techniques and modern approaches will be shared. Periodic courses and workshops conducted in agricultural offices were also considered as preferred places of meeting in determining and fulfilling knowledge required by farmers.

Training events organized by IADA are opportunities for interaction between farmers and expert trainers. This interaction assists in shifting values and attitudes toward new practices. IADA organized beneficial courses for farmers almost every month. This has been quoted by respondent: Usually, we will meet extension officers in the farmer's residence only. We do not have to visit the agricultural office in Kuala Selangor. IADA provided periodic workshops to help us (farmers) enriching our knowledge and skills.

\section{B. Sharing of Best Practices}

Farmers willing to make changes if they are trained by experienced officers. Farmers are ready to change their style of doing and completing tasks if they found that new techniques helps them to minimize loss and save their time.

Technology and information owned by farmers in IADA Barat Laut Selangor could be shared by farmers in other 
states. Their best practices were compiled and taught to neighboring farmers in a pilot program. Information sharing and technology transfer occur indirectly when farmers are hired to poisoning and fertilizing in other paddy fields in IADA. Farmers, under the pilot program, are schooled in modern techniques of field management which involve close monitoring of every stage of the 110-day life cycle of paddy and the scheduled use of pesticides and fertilizer.

High yields heavily dependent on the management of paddy field. Even though the paddy area is wide enough, infrastructure and management system should be consistently managed otherwise it will result in low paddy production. Drainage systems applied in Sekinchan are very systematic. Water equally supplied to every square of paddy plots. Apart from that, paddy farmers in IADA Barat Laut Selangor have used transplant machine technology since four years ago which also contribute to the increment of paddy production. The usage of technology from east countries such as from Japan and Taiwan is not new to Malaysia. However, this kind of technical system and technology is always underemployed by farmers due to lack of exposures.

For Selangor paddy farmers, it's not about survival anymore or making a decent income. It is about pride. In the rice belt of Selangor, paddy is as serious and as competitive business as electronics. Some of the farmers wake up at $3 \mathrm{am}$ to devise new cocktails of pesticide and fertilizer that they think will make their paddy stalks grow stronger and fatter. They get subsidized fertilizer and pesticide from the government while a web of irrigation canals and aqueducts ensures that the fields are watered.

\section{Collaboration within the Community of Practice}

In the central region, it was found that farmers working closely and cooperatively in performing their agricultural activities. Active farmers in central region prefer working in a small group and willing to share information with other community. They believe in the power of networking as by working in a group could encourage development of social skills and lead to the enhancement and sustainability of the agriculture sector.

In general, active farmers are more advanced and produce more result compared to other farmers. One of the factors of their success is their willingness to share and exchange useful information and knowledge. They are more cooperative and have strength in capital aspect where through high capital those farmers may hire more workers and consistently seek for modern and the best technologies to increase yield productivity level.

Farmers connected with suppliers in order to get the latest information about equipment and technologies besides working cooperatively with extension officers. Farmers in central region easily adopt new technology as it will increase their yield productivity level. Most of the farmers engaged with informal cooperation. They cooperate in the form of helping each other in field works. Other common forms of cooperation are use of machinery and transportation, common sales of agricultural products, purchase of production input and exchange of information.
In addition, farmers in central region exposed with a lot of committees and organization related to paddy farming activities and consulting services.

\section{COnsultations}

Government agencies also actively negotiate on behalf of farmers with service providers on rates for renting out machines to plant, till and harvest the crop. Paddy farmers all over the country get the same types of assistance from the government as the modern techniques are similar. It is just a matter of how farmers utilize the facilities provided.

There are no any specific procedures in consultation process between farmers and extension officers. Farmers may consult with extension advisors in any areas of concerned. Main consultation services included latest agricultural information, machines and equipment and demo of new technology from suppliers.

\section{CONCLUSIONS}

Generating knowledge requires communication and considered as a social process. There is no knowledge in existence that has not been born out of preexisting knowledge and that which exists today came from that which existed before [7]. For this reason, to share knowledge is a condition for its creation. Through the process of sharing, knowledge is not lost; rather it is multiplied and enriched. Farmers' knowledge and experiences on climate change, local farmer innovations, natural resources management and indigenous knowledge could be captured in order to document best practices in agricultural activities.

\section{ACKNOWLEDGMENT}

We would like to show our greatest appreciation to associate professor dr. hj. laili hashim, dean of faculty of information management. special thanks to our beloved family and colleague for their support, understanding and help during the completion on this project and study.

\section{REFERENCES}

[1] Official website of Jabatan Pertanian Negeri Selangor. [Online]. Available: http://pertanian.selangor.gov.my/main.php

[2] I. V. Malhan, "Developing corporate culture in the Indian university libraries: problems and challenges of change management," Library Management, vol. 27, no. 6/7, pp. 486-493, 2006.

[3] B. V. den Hooff and L. Hendrix, "Eagerness and willingness to share: the relevance of different attitudes towards knowledge sharing," in Proc. the5th European Conference on Organizational Knowledge, Learning and Capabilities: Innsbruck, Austria, 2004.

[4] X. D. Ding. (2006). Policy perspectives: Innovation and technology transfer in Chinese agriculture. Journal of Small Business and Enterprise Development. [Online]. 13 (2). pp. 242-247. Available: http://www.emeraldinsight.com

[5] S. Zakaria and H. Nagata. (2010). Knowledge creation and flow in agriculture: The experience and role of the Japanese extension advisors. Library Management. [Online]. 31 (1). pp. 27-35. Available http://www.emeraldinsight.com

[6] P. Mufara, Living the Dream: The Chambeshi Rice Farmers' Association Story, SNV Netherlands Development Organisation, 2009.

[7] S. Burch, Knowledge Sharing for Rural Development: Challenges, Experiences and Methods, US: ALAI, 2007. 


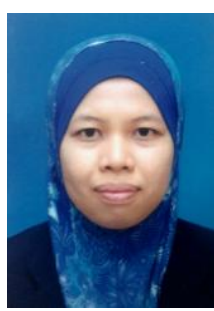

Hanis Diyana Kamarudin was born in Perak, Malaysia on April 13, 1984. She works as a lecturer of records and archives management at the Faculty of Information Management, Universiti Teknologi MARA Malaysia (UiTM). She received a bachelor degree of records management and Master of Science in Information Management from Universiti Teknologi MARA. Her major areas of research are in electronic records management, business records management, oral history and documentation and knowledge

management.

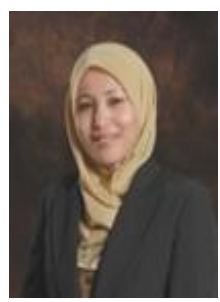

Nor Erlissa Abd Aziz works as a lecturer of information systems management at the Faculty of Information Management, Universiti Teknologi MARA Malaysia (UiTM). She received Bachelor of Information Studies (Hons) Information System Management, and Master in Information Management from Universiti Teknologi MARA. Her research and teaching interest is in information systems, multimedia and e-commerce.

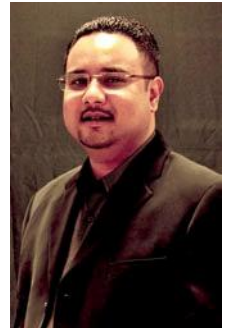

Muhammad Khairulnizam Zaini works as a lecturer of information systems management at the Faculty of Information Management, Universit Teknologi MARA Malaysia (UiTM). He received Bachelor of Information Studies (Hons) Information System Management, and Master in Information Management from Universiti Teknologi MARA. His research and teaching interest are in Information Systems Analysis \& Design and Knowledge Management Systems.

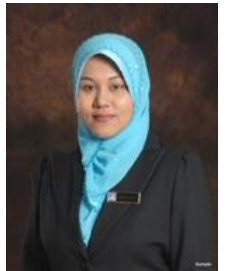

Nor Zaina Zaharah Mohd Ariff works as a lecturer of information systems management at the Faculty of Information Management, Universiti Teknologi MARA Malaysia (UiTM). She received Bachelors of Science (Hons) Information System Management from Universiti Teknologi MARA Malaysia and Master of Science Library Information Science from Universiti Malaya, Malaysia. Her research and teaching interest is in information sources \& services, humanities, computerized textual information management, automated library system and organization of information. 